\title{
Pengembangan Pembelajaran Statistika Berbasis Praktikum Aplikasi \\ Software SPSS dengan Bantuan Multimedia untuk Mempermudah Pemahaman Mahasiswa terhadap IImu Statistika
}

\author{
Slamet Riyanto ${ }^{1}$ dan Fatim Nugrahanti ${ }^{2}$ \\ ${ }^{1,2}$ Program Studi S1Teknik Informatika Universitas PGRI Madiun \\ 'mm_riset@yahoo.co.id; fatimmadiun@yahoo.co.id
}

\begin{abstract}
Abstrak
Penelitian ini bertujuan untuk mengembangkan suatu model pembelajaran statistika dengan mengkombinasikan antara teori dan praktik serta memanfaatkan aplikasi software SPSS dengan tutorial multimedia pada mahasiswa Teknik Informatika di Fakultas Teknik Universitas PGRI Madiun. Desain penelitian ini adalah Penelitian Tindakan Kelas (PTK) dengan dua siklus, dengan mengambil sampel sebanyak 23 mahasiswa semester 2 pada mata kuliah Statistik di Program Studi Teknik Informatika. Teknik analisis yang digunakan adalah analisis kualitatif yang berasal dari dokumentasi dan observasi. Hasil penelitian ini memberikan informasi bahwa pembelajaran statistik berbasis praktikum aplikasi software SPSS dengan bantuan multimedia membantu mahasiswa dalam memahami konsep-konsep dasar statistik, langkah-langkah analisis dengan program SPSS serta cara membaca makna angka statistik dari hasil pengolahan data. Hasil Penelitian Tindakan Kelas memberikan informasi bahwa kemampuan mahasiswa dalam menjalankan aplikasi SPSS dan cara membaca makna angka statistik dari output SPSS dinilai cukup baik dan mengalami peningkatan dari siklus satu. Untuk pembelajaran statistik berbasis praktikum aplikasi software SPSS dengan bantuan multimedia perlu dikembangkan dengan menggunakan aplikasi Moodle. Moodle merupakan suatu aplikasi yang digunakan untuk media pembelajaran dalam bentuk website.
\end{abstract}

Kata kunci: media pembelajaran, statistika, multimedia, moodle

\section{PENDAHULUAN}

Adanya persepsi negatif terhadap mata kuliah statistik ini perlu dihilangkan, dan mahasiswa harus diubah pola pikirnya agar lebih termotivasi untuk mempelajari statistika. Untuk mengubah pola pikir mahasiswa terkait dengan mata kuliah statistika tersebut, dapat dilakukan dengan cara mengubah metode atau model pembelajarannya mata kuliah statistika. Selama ini, dosen lebih banyak menerapkan pembelajaran konvensional dan meminta mahasiswa menghitung angka-angka statistik dengan rumus secara manual. Metode konvensional ini sering menyebabkan mahasiswa merasa jenuh dan malas, karena mahasiswa kurang memperoleh manfaat dari pembelajaran tersebut.

Untuk itu, perlu adanya pengembangan pembelajaran mata kuliah statistika, di mana model dan metode pembelajaran mata kuliah statistika dapat dilakukan dengan cara teori dan praktik dengan perbandingan $30 \%$ untuk teori dan $70 \%$ untuk praktik. Selain itu, kegiatan pembelajaran praktik mata kuliah statistika dapat dilakukan dengan bantuan aplikasi SPSS (Statistical Product and Service Solution). SPSS merupakan aplikasi program statistik dengan kemampuan perhitungan statistik yang tinggi, sehingga memudahkan pengguna dalam analisis data. Berbeda dengan pembelajaran konvensional, pengembangan pembelajaran ini diharapkan mampu meningkatkan minat dan motivasi mahasiswa untuk belajar statistika.

Untuk

pengembangan

pembelajaran statistika dengan aplikasi software SPSS akan dibantu dengan bantuan multimedia, yaitu pada pembelajaran multimedia ini akan disajikan berbagai bentuk tutorial (video) dalam menjalankan analisis data dengan SPSS. Mengingat bahwa dalam program SPSS terdapat puluhan cara 
analisis baik parametrik maupun nonparametrik, sehingga panduan tutorial yang bersifat praktis dan aplikatif sangat dibutuhkan selain adanya modul pembelajaran.

Tujuan penelitian ini adalah untuk mengembangkan suatu model pembelajaran statistika dengan mengkombinasikan antara teori dan praktik serta memanfaatkan aplikasi software SPSS dengan tutorial multimedia pada mahasiswa Teknik Informatika di Fakultas Teknik Universitas PGRI Madiun.

\section{TINJAUAN PUSTAKA}

Statistika

Menurut Husaini (2008), statistika merupakan cara untuk peroleh data, mengolah data, menarik kesimpulan, dan membuat keputusan berdasarkan analisis data yang dikumpulkan. Tiro dalam Karwati (2015) menyatakan bahwa statistika cara-cara ilmiah untuk mengumpulkan, mengorganisasi, menyajikan, dan menganalisis data, serta menarik kesimpulan sahih dan mengambil keputusan layak berdasarkan analisis yang dilakukan.

Dengan demikian statistika adalah suatu metode atau cara untuk mengumpulkan, menganalisis data, dan menarik kesimpulan serta membuat keputusan berdasarkan analisis yang dilakukan sesuai dengan langkah-langkah atau prosedur ilmiah.

\section{Pembelajaran berbasis Praktikum SPSS Strategi belajar dengan} praktikum dapat mendukung siswa untuk mengembangkan keterampilan dan kemampuan berpikir (hands on dan minds on). Hal ini sesuai dengan pendapat Gabel (Hayat dkk, 2011) bahwa kegiatan laboratorium atau praktikum dapat memberikan kesempatan pada siswa untuk mengembangkan keterampilan dan kemauan berpikir logis. Dengan pembelajaran praktikum siswa dirangsang untuk aktif dalam memecahkan masalah, berpikir kritis dalam menganalisis permasalahan dan fakta yang ada, serta menemukan konsep dan prinsip, sehingga tercipta kegiatan belajar yang lebih bermakna dengan suasana belajar yang kondusif. Pembelajaran berbasis praktikum merupakan pembelajaran yang berpusat pada praktikum dengan materi tertentu. Menurut Kloper (1990 dan White 1996 dikutip oleh Hayat dkk, 2011) praktikum merupakan bagian yang sangat penting dalam suatu kegiatan pembelajaran, khususnya pembelajaran sains.

Kegiatan pembelajaran praktikum mata kuliah Statistika dengan aplikasi software SPSS merupakan bagian integral dari kegiatan belajar mengajar, khususnya mahasiswa Teknik Informatika. Hal ini menunjukkan betapa pentingnya peranan kegiatan praktikum untuk mencapai tujuan pembelajaran statistika yang berbasis aplikasi statistik.

Keberadaan praktikum dalam pembelajaran statistika didukung oleh para pakar pendidikan. Hodson (1996) dalam terjemahan Hayat dkk, (2011) menyatakan bahwa penggunaan praktikum dapat: (1) siswa lebih termotivasi karena sesuai dengan minatnya, (2) menambah kemampuan ketrampilan dalam menyelesaikan suatu kasus, (3) mengembangkan konsep yang dipelajari, (4) dapat mengembangkan suatu solusi permasalahan, (5) sikap ilmiah semakin bertambah, (6) keterampilan ilmiah mahasiswa semakin terasah.

\section{Pembelajaran Berbasis Multimedia} Multimedia menurut Rosch (1996) dalam Munir (2013) adalah perpaduan media visual dan non visual yang telah dikemas dalam bentuk file digital, sehingga pesan yang disampaikan tercapai. Multimedia merupakan suatu kombinasi data atau media dalam menyampaikan suatu informasi yang lebih menarik dan diminati.

\section{METODE PENELITIAN}

Penelitian ini dilakukan pada mahasiswa program studi Teknik Informatika Universitas PGRI Madiun 
tahun pelajaran 2016/2017. Waktu penelitian mulai dari kesiapan sampai dengan penyusunan laporan penelitian dalam bentuk PTK dilaksanakan selama satu tahun terhitung mulai bulan Mei September 2017. Desain penelitian ini menggunakan desain Penelitian Tindakan Kelas. Dalam pelaksanaan penelitian kelas ini menggunakan dua siklus, masing-masing siklus dilaksanakan dalam waktu 4 jam pelajaran (4 x 50 menit).

\section{HASIL PENELITIAN}

\section{Siklus 1}

Subjek penelitian ini adalah mahasiswa semester 2 tahun ajaran 2016/2017 untuk mata kuliah Statistik pada Program Studi Teknik Informatika Universitas PGRI Madiun. Ruang kelas yang digunakan saat proses pembelajaran adalah menggunakan ruang laboratorium komputer dengan kapasitas 30 mahasiswa, sedangkan jumlah subjek penelitian ini sebanyak 22 mahasiswa.

Desain penelitian ini adalah Penelitian Tindakan Kelas dengan menggunakan pendekatan siklus, di mana penelitian ini terdiri dari 2 siklus, masing-masing siklus memiliki alokasi waktu 4 x 50 menit atau 2 kali pertemuan.

Untuk siklus I diberikan pada pertemuan kuliah ke-9 dan 10, dengan materi uji independent samples t test. Pada pertemuan ke-9, mahasiswa telah diberikan bahan materi tentang Uji Independent samples t test, input data dan tutorial SPSS dalam bentuk video dan audio. Materi Uji Independent samples t test ini telah dipersiapkan dosen dan disimpan dalam folder file di masingmasing komputer. Pada waktu 15 menit pertama, dosen menjelaskan secara umum manfaat uji independent samples $t$ test untuk analisis kuantitatif dan contoh penelitian yang menggunakan uji independent samples t test. Kemudian 75 menit selanjutnya, mahasiswa membaca materi uji independent samples t test dan melihat tutorial uji independent samples $\mathrm{t}$ test yang telah dipersiapkan dosen. Selain itu, dengan waktu 75 menit ini juga diberikan kesempatan bagi mahasiswa untuk bertanya dan diskusi terkait dengan uji independent samples $t$ test. Selanjutnya 10 menit terakhir, dosen memberikan input data untuk diolah menggunakan uji independent samples t test dengan program SPSS. Input data ini sebagai tugas rumah yang harus dikerjakan mahasiswa dan hasilnya dipresentasikan berdasarkan kelompok yang terdiri dari 2 mahasiswa.

Untuk pertemuan ke-10, pada siklus 1 membahas hasil analisis data dari input yang diberikan pada pertemuan ke-9. Masing-masing kelompok mempresentasikan hasil analisis data serta interprestasi hasil analisis. Dari unjuk kerja tersebut, dosen melakukan penilaian terhadap hasil kerja mahasiswa dan dosen memberikan penilaian seberapa dalam pemahaman mahasiswa terhadap materi yang telah diberikan.

Dari siklus 1 tersebut, maka dapat dievaluasi kegiatan pembelajaran statistik berbasis praktikum aplikasi software SPSS dengan bantuan multimedia, di mana ada beberapa kelemahan dalam proses pembelajaran, yaitu:

1. Untuk langkah-langkah analisis data dengan cara aplikasi software SPSS, mahasiswa melakukan dengan cara yang benar sesuai tutorial yang dipelajarinya. Akan tetapi, masalah muncul saat mahasiswa melakukan interprestasi dari hasil pengolahan data. Sebagian besar mahasiswa yang bingung menjelaskan makna dari angka statistik yang muncul dari hasil pengolahan data dengan program SPSS.

2. Mahasiswa tidak mau bertanya kepada dosen di luar jam mengajar, sehingga disaat mengerjakan tugas rumah hasilnya kurang optimal. Selain itu, mahasiswa bersikap pasif apabila menemukan masalah dalam interpretasi data penelitian. 
Refleksi yang dapat perbaikan di siklus 2 adalah sebagai berikut:

1. Membuat tutorial yang lebih detail dalam menjelaskan makna angka statistik dari hasil pengujian SPSS

2. Dosen memberikan kesempatan kepada mahasiswa untuk melakukan diskusi atau tanya jawab terkait tugas kuliah dengan media WhatsApp (WA) di luar jam kuliah.

3. Perlu adanya studi kasus lebih dari satu untuk meningkatkan pemahaman mahasiswa terhadap data dan hasil pengolahan data.

\section{Siklus 2}

Untuk siklus 2 diberikan pada pertemuan kuliah ke-11 dan 12, dengan materi uji paired samples test. Pada pertemuan ke-11, mahasiswa telah diberikan bahan materi tentang Uji Paired Sample Test, input data dan tutorial SPSS dalam bentuk video dan audio. Materi Uji Paired Sample Test ini telah dipersiapkan dosen dan disimpan dalam folder file di masing-masing komputer. Pada waktu 15 menit pertama, dosen menjelaskan secara umum manfaat uji Paired Sample Test untuk analisis kuantitatif dan contoh penelitian yang menggunakan uji Paired Sample Test. Kemudian 75 menit selanjutnya, mahasiswa membaca materi uji Paired Sample Test dan melihat tutorial uji Paired Sample Test yang telah dipersiapkan dosen. Selain itu, dengan waktu 75 menit ini juga diberikan kesempatan bagi mahasiswa untuk bertanya dan diskusi terkait dengan uji Paired Sample Test. Selanjutnya 10 menit terakhir, dosen memberikan input data untuk diolah menggunakan uji Paired Sample Test dengan program SPSS. Input data ini sebagai tugas rumah yang harus dikerjakan mahasiswa dan hasilnya dipresentasikan berdasarkan kelompok yang terdiri dari 2 mahasiswa.

Untuk pertemuan ke-12, pada siklus 2 membahas hasil analisis data dari input yang diberikan pada pertemuan ke-11. Masing-masing kelompok mempresentasikan hasil analisis data serta interprestasi hasil analisis. Dari unjuk kerja tersebut, dosen melakukan penilaian terhadap hasil kerja mahasiswa dan dosen memberikan penilaian seberapa dalam pemahaman mahasiswa terhadap materi yang telah diberikan.

Dari hasil observasi siklus 2, diketahui bahwa ada peningkatan pemahaman mahasiswa terhadap materi yang diberikan. Mahasiswa menjalankan aplikasi SPSS dengan baik dan lancar, dan mahasiswa dinilai cukup paham dalam menjelaskan makna angka statistik yang muncul dari output SPSS. Selain itu, mahasiswa juga memahami konsep dasar dari uji Paired Sample Test dan tujuan dari uji Paired Sample Test tersebut. Ini menunjukkan bahwa tutorial yang diberikan dosen telah banyak membantu mahasiswa dalam menjalankan aplikasi SPSS serta membaca makna angka statistik dari output pengolahan data.

Dari hasil siklus 2, maka hasil refleksi untuk proses perbaikan pembelajaran statistik berbasis praktikum aplikasi software SPSS dengan bantuan multimedia, yaitu:

1. Kemampuan mahasiswa dalam menjalankan aplikasi SPSS dan cara membaca makna angka statistik dari output SPSS dinilai cukup baik dan mengalami peningkatan dari siklus 1 .

2. Tugas yang dikerjakan mahasiwa memiliki jumlah data yang sama, sehingga output yang keluar memiliki kesamaan dan ada kecenderungan mahasiswa melakukan copy paste dengan kelompok lainnya. Untuk selanjutnya dosen perlu menyediakan input data dalam jumlah ideal, dan mahasiswa dapat melakukan select data secara random dengan jumlah yang bervariasi. Ini bertujuan untuk mendapatkan nilai output SPSS yang berbeda-beda antara 
kelompok satu dengan yang lainnya.

Nilai Hasil Belajar Mahasiswa

Nilai hasil belajar mahasiswa tidak didasarkan atas penilaian benar atau salah dari jawaban yang diberikan. Akan tetapi lebih didasarkan atas tinggi atau rendahnya pemahaman mahasiswa dalam melakukan interprestasi data penelitian. Pada penelitian ini juga tidak dilakukan pre test maupun post test, akan tetapi dosen melakukan penilaian objektif terhadap kemampuan mahasiswa dalam menerima dan menyelesaikan tugas yang diberikan dosen. Dengan kata lain, penilaian untuk penelitian ini didasarkan pada hasil observasi dosen terhadap aktivitas belajar mahasiswa.

Pada tahun ajaran 2016/2017 untuk Program Studi Teknik Informatika semester dua memiliki tiga kelas. Dari tiga kelas tersebut, dipilih satu kelas yang digunakan untuk penelitian terkait dengan pembelajaran statistik berbasis praktikum aplikasi software SPSS dengan bantuan multimedia, yaitu kelas 2B. Untuk kelas lainnya masih menggunakan metode pembelajaran tanpa multimedia dan pembelajaran dilakukan di ruang kelas. Hasil akhir dari nilai mahasiswa yang diterapkan pembelajaran statistik berbasis praktikum aplikasi software SPSS dengan bantuan multimedia memiliki nilai Ujian Akhir Semester yang lebih tinggi dibandingkan dengan kelas konvensional.

Hasil ini menunjukkan bahwa pembelajaran statistik berbasis praktikum aplikasi software SPSS dengan bantuan multimedia membantu mahasiswa dalam memahami konsepkonsep dasar statistik, langkah-langkah analisis dengan program SPSS serta cara membaca makna angka statistik dari hasil pengolahan data.

Hasil penelitian ini sejalan dengan penelitian Sianturi (2013), bahwa aplikasi yang berisi pembelajaran komputer yang berupa visualisasi materi tentang pembelajaran statistika dengan tampilan yang menarik dapat meningkatkan pemahaman oleh user yang menggunakannya.
DISKUSI

Peneliti menilai bahwa proses pembelajaran statistik berbasis praktikum aplikasi software SPSS dengan bantuan multimedia dapat berjalan dengan lancar dan peneliti menyadari perlu adanya perbaikan untuk dari metode yang telah diterapkan. Untuk tahap berikutnya, peneliti melakukan pembenahan terhadap pembelajaran statistik berbasis praktikum aplikasi software SPSS dengan bantuan multimedia dengan cara membuat pembelajaran elearning dengan Moodle.

Cara ini dinilai akan lebih baik karena sistem yang digunakan adalah online dan pada e-learning dengan Moodle menyediakan fasilitas diskusi antara dosen dengan mahasiswa. Selain itu, elearning dengan Moodle akan menata materi pembelajaran secara terstruktur dan mahasiswa dapat mengakses di mana saja dengan fasilitas internet.

\section{KESIMPULAN}

Hasil penelitian ini memberikan informasi bahwa pembelajaran statistik berbasis praktikum aplikasi software SPSS dengan bantuan multimedia membantu mahasiswa dalam memahami konsep-konsep dasar statistik, langkahlangkah analisis dengan program SPSS serta cara membaca makna angka statistik dari hasil pengolahan data.

Hasil Penelitian Tindakan Kelas memberikan informasi bahwa kemampuan mahasiswa dalam menjalankan aplikasi SPSS dan cara membaca makna angka statistik dari output SPSS dinilai cukup baik dan mengalami peningkatan dari siklus 1 .

\section{REKOMENDASI}

1. Untuk pembelajaran statistik berbasis praktikum aplikasi software SPSS dengan bantuan multimedia perlu dikembangkan dengan menggunakan Moodle.

2. Dosen perlu memperbanyak referensi video tutorial yang disupport dengan input data SPSS, sehingga mahasiswa dapat melakukan uji coba yang lebih banyak. Selain itu, tutorial juga ditekankan pada informasi cara 
membaca angka statistik dari output SPSS.

3. Pembelajaran statistik berbasis praktikum aplikasi software SPSS dengan bantuan multimedia bisa diterapkan di kelas dengan menggunakan laptop setelah dosen mengupload materi perkuliahan secara online melalui media pembelajaran Moodle.

4. Dosen disarankan membuka forum diskusi dalam pembelajaran Moodle. Adanya forum diskusi dan konsultasi akan menambah keaktifan mahasiswa dalam bertanya terkait kesulitan dalam mengerjakan tugas kuliah.

\section{DAFTAR PUSTAKA}

Hayat, Muhammad Syaipul; Anggraeni, Sri dan Redjeki, Sri. 2011. Pembelajaran Berbasis Praktikum Pada Konsep Invertebrata Untuk Pengembangan Sikap Ilmiah Siswa. Bioma, Vol. , No. 2. Hlm. 141-152.
Hodson, D. 1996. Practical Work in School Science: Exploring some directions for change. International Journal Science Education. Vol. 18. No. 7. Pp. 755-760.

Husaini, Usman. 2008. Pengantar Statistika. Yogyakarta: Sinar Grafika Offset.

Karwati. 2015. Penerapan Metode Pembelajaran Problem Solving dalam Meningkatkan Hasil Belajar Statistika Mahasiswa pada Fakultas Tarbiyah dan Ilmu Keguruan IAIN Palu. ISTIQRA, Jurnal Penelitian Ilmiah, Vol. 3 No. 1. Hlm. 83-99.

Munir. 2013. Multimedia konsep dan Aplikasi dalam Pendidikan. Bandung : Alfabeta.

Sianturi, Jerri Jhonson. 2013. Perancangan Aplikasi Pembelajaran Statistika dengan Computer Based Instruction. Jurnal Pelita Informatika Budi Darma. Volume : IV, Nomor: 2, ISSN : 2301-9425. Hlm. 95-100 